\title{
Sciendo
}

DOI: 10.1515/aon-2018-0017

\author{
STEPAN SAVCHUK ${ }^{1)}$, ALINA KHOPTAR ${ }^{2)}$ \\ 1) Polish Air Force University, Dęblin, Poland \\ ${ }^{2)}$ Lviv Polytechnic National University, Ukraine
}

\section{ESTIMATION OF SLANT TROPOSPHERIC DELAYS FROM GNSS OBSERVATIONS WITH USING PRECISE POINT POSITIONING METHOD}

\begin{abstract}
Global Navigation Satellite Systems give opportunities for atmospheric parameters analysis in behalf of solving many atmosphere monitoring tasks. The authors of this article demonstrated possibility of slant tropospheric delays determination with using precise point positioning method - PPP. The atmospheric parameters, retrieved from GNSS observations, including zenith tropospheric delays, horizontal gradients, and slant tropospheric delays, are analyzed and evaluated. It was obtained slant tropospheric delays, along the satellite path, for each satellite, at a certain elevation angle and azimuth, at each time, instead of obtaining a single zenith tropospheric delay composed of all visible satellites at one time. The results obtained proved that suggested method was correct.
\end{abstract}

\section{Keywords:}

Global Navigation Satellite Systems (GNSS), atmosphere monitoring, precise point positioning method (PPP), zenith tropospheric delay, slant tropospheric delay

\section{INTRODUCTION}

It is known that the signals of global navigation satellite systems - GNSS - can be used to study the processes taking place in the Earth's atmosphere. Over the last decade the applying of GNSS observations for atmospheric monitoring is widely used and is now an urgent area of research in the atmosphere physics - GNSS - meteorology. However, special perspective of practical application to such data is manifests in determining tropospheric delays. The big advantage is all-weather 
of GNSS: these systems work in decimeter radio waves, so that their signals are almost free from the influence of aerosols, clouds and rain drops [21]. That allows evaluating the influence of various atmospheric effects on radio waves propagation.

In particular, currently there are many different methods of the atmospheric sounding in which the vertical profiles of temperature, pressure and humidity distributions in the troposphere are deterministic functions of height and suggest local meteorological parameters measurements near the Earth's surface. These methods conventionally divided into contact and non-contact methods, the essence of which is limited to the determination the refractive index of air based on meteorological parameters, or based on direct measurements. To contact measurements are used refractometers, providing a more accurate data compared with the results obtained in the calculation of meteorological parameters. The undeniable advantage of using refractometers is the possibility of detailed study of variations in the refractive index of air. But, the launch of radiosondes for analysis is quite expensive and often not performed more than 2 times per day, which makes it impossible to assess behavior changes of the refractive index of air during the day. The use of non-contact methods that are devoid of this disadvantage is a promising direction for atmospheric monitoring [18].

The Earth's atmosphere can be presented as an environment that consists of two areas: the electrically neutral area, which is located near the Earth's surface (troposphere, stratosphere) and located above - the electrically charged area - ionosphere. It should be understood and took into account the basic physical effects of these areas on GNSS observations. In case of the ionosphere, where the phase refractive index in the radio ranges is less than one and dependent on the frequency, it arise group delays and phase advance of signals. Due to this effect, it is possible to extract ionospheric delays in observations at different carrier frequencies. However, in case of the troposphere, the refractive index of air is not depend on frequency in the range of GNSS signals, therefore tropospheric delays modeling is remains a rather difficult task. Tropospheric delays are divided into hydrostatic and wet components for which empirical models were created. These models have a number of disadvantages related with the lack of accounting of real meteorological situation, so the effect of troposphere on the accuracy of GNSS observations remains the main source of errors [18].

There are a number of works which devoted to the use of different approaches determine tropospheric delays according GNSS observations [1, 9, 17, 19, 20, 24]. In world practice in the in open access are not many sources, which would fully describe the solution to this task. It is worth noting the algorithms that are the basis of scientific software - for example, GipsyX [7], Bernese GNSS Software [3] and GAMIT/GLOBK [6] - that is the intellectual property of developer organizations 
and usually are not covered in detail in open sources. Recently, special attention is attracted software developed by Jet Propulsion Laboratory of California Technical Institute GipsyX, GNSS observations processing in which is based on using the precise point positioning (PPP) method [26]. It can provide millimeter accuracy results with only one GNSS receiver.

Thus, it is relevant creating methods and algorithms that will able to reliably the solving of determining tropospheric delays problem. This article focuses on the determination of slant tropospheric delay ( STD) by GNSS observations using the PPP method.

\section{METHOD OF DETERMINING THE TROPOSPHERIC DELAYS}

Principle of GNSS observations is to measure the distance from antenna on the object of observations, which coordinates must be gotten, to satellites which positions in the current period of time is known with high accuracy. Recently, the PPP method becomes widespread, because the results of observations from one station are processed independently of observations at other stations [13]. To compensate for major errors that occur during absolute GNSS observations in this method, it is use precise ephemeris and satellite clock corrections, information on the satellite signal delay in the ionosphere and the troposphere and others. Fig. 1 shows schematically the principle of GNSS observations [4].

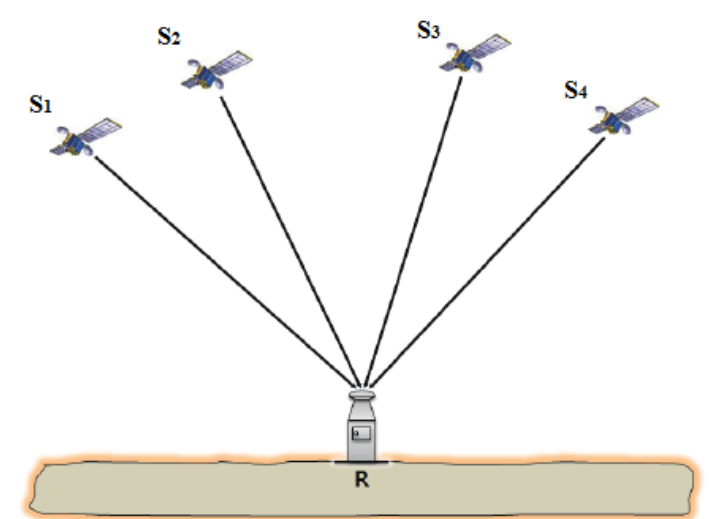

Fig. 1. Principle of GNSS observations with the using of PPP method. Source: Authors.

Taking into account all corrections, which is necessary for observations at station $R$ to satellite $S$, the general equation of this method will be as follows [12]: 


$$
\Delta \tau_{R}^{S, G N S S}=\left|r_{i}^{S}-R r_{e, R}\right|+c \cdot \delta t_{R}-c \cdot \delta t^{S}+\delta_{\text {trop }, R}^{S}+\delta_{\text {ion }, R}^{S}+\delta_{r e l, R}^{S}+\delta_{m u l t, R}^{S}+\varepsilon_{R}^{S},
$$

where:

$\Delta \tau_{R}^{S, G N S S}$ - code pseudoranges or signal phase from station $R$ to satellite $S$ from GNSS observations;

$c$ - speed of light;

$r_{i}^{S}$ - position of satellite $S$ in the inertial reference system (orbital parameters, gravitational field coefficients);

$r_{e, R}$ - position of station $R$ in geocentric reference system (coordinate of station);

$R$ - Earth rotation matrix (Earth orientation parameters);

$\delta t_{R}$ - clock errors at the station $R$ (station clock parameters);

$\delta_{t r p, R}^{S}-$ signal delay due troposphere (tropospheric parameters);

$\delta_{\text {ion,R }}^{S}$ - signal delay due ionosphere (ionospheric parameters);

$\delta_{r e l, R}^{S}-$ relativistic corrections;

$\delta_{\text {phas }}^{S}$ - phase center bias of satellite and receiver;

$\delta_{m u l t}^{S}$ - errors of ray multiplicity;

$\varepsilon_{R}^{S}$ - measurements errors.

Taking into account all the members in equation (1) allows obtaining high-precision geodetic parameters including tropospheric parameters. The influence of troposphere on GNSS observations is manifested in the signal delay which moves from the satellite to the receiver. This delay depends on temperature, pressure, humidity, and the locations of receiver antenna and transmitter. It is known that integrating of basic formula to account for tropospheric delay in the direction of zenith gives hydrostatic (dry) and wet components of zenith delay, where the total zenith delay is [10]:

$$
Z T D=Z H D+Z W D
$$

where:

$Z T D$ - total zenith tropospheric delay,

$Z H D$-hydrostatic (dry) component of zenith tropospheric delay, depending on the value of surface atmospheric pressure.

Usually, $Z H D$ can be defined at millimeter-level accuracy. $Z W D$ - wet component of zenith troposphere delay that depends on the distribution of water vapor 
in the atmosphere. These components can be calculated from GNSS observations by the use of PPP method, such as in GipsyX software.

In reality GNSS signals do not go in the zenith direction, but from slant directions. Tropospheric delays depend on the actual path of the signal through the atmosphere, and therefore are also functions of elevation angle of satellite. STD is the total delay of GNSS signals in a neutral atmosphere along of its way from the satellite to the receiver antenna on the Earth's surface [11]. In STD determining there are a series of difficulties, because $S T D$, under the influence of atmospheric conditions along the slant path that has rapid fluctuations in space and in time, so it is very difficult to model it accurately [15]. The STD values can reach to 25 meters at low elevation angles [14]. So it is important to consider the value of tropospheric gradients. For STD determination it is necessary to display ZTD and gradients in the slant direction via a mapping function. These mapping functions are described in detail in [2]. Thus, the STD values between the station $R$ and satellite $S$ can be written as follows:

$S T D=m_{h}(e)\left[Z H D+\operatorname{ctg} e\left(G_{N}^{h} \cos a+G_{E}^{h} \sin a\right)\right]+m_{w}(e)\left[Z W D+\operatorname{ctg} e\left(G_{N}^{w} \cos a+G_{E}^{w} \sin a\right)\right]$

where:

$S T D$ - is a slant tropospheric delay,

$e$ - elevation angle,

$a$ - azimuth,

$G_{N}$ - north gradient,

$G_{E}$ - east gradient,

$m_{h}(e)$ and $m_{w}(e)$ - mapping function of $Z H D$ and $Z W D$ in accordance.

\section{MATERIALS RESEARCH}

The main purpose of this study was to develop and test algorithms for solving problems of STD determination along the path of each satellite, for certain values of the elevation angle and azimuth, instead of getting one ZTD value consisting of all visible satellites at once. Standard process of STD determination performed in two stages: first modeling the ZTD, and after displaying STD in a slant direction for each satellite.

Assume that at a maximum distance of $10 \mathrm{~km}$ between GNSS observation stations and measurements on aerological stations are in the same atmospheric 
conditions, and the impacts on the atmosphere are the same. For this study it was chosen GNSS stations located close to the aerological stations in Ukraine, Poland and Slovakia. Fig. 2 shows a map of research stations location, and Table 1 shows the coordinates and distance between selected stations.

In the first stage of our research GNSS observations data processed by the software GipsyX, and as a result it was gotten ZTD values. The important point at this stage was to obtain the most accurate ZTD values, when the final results of processing GNSS observations were compared with the results of sounding. This process can be divided into 3 stages:

- data collection of sounding meteorological data profiles of aerological stations and their subsequent processing;

- data collection of GNSS stations and their subsequent processing;

- results comparison.

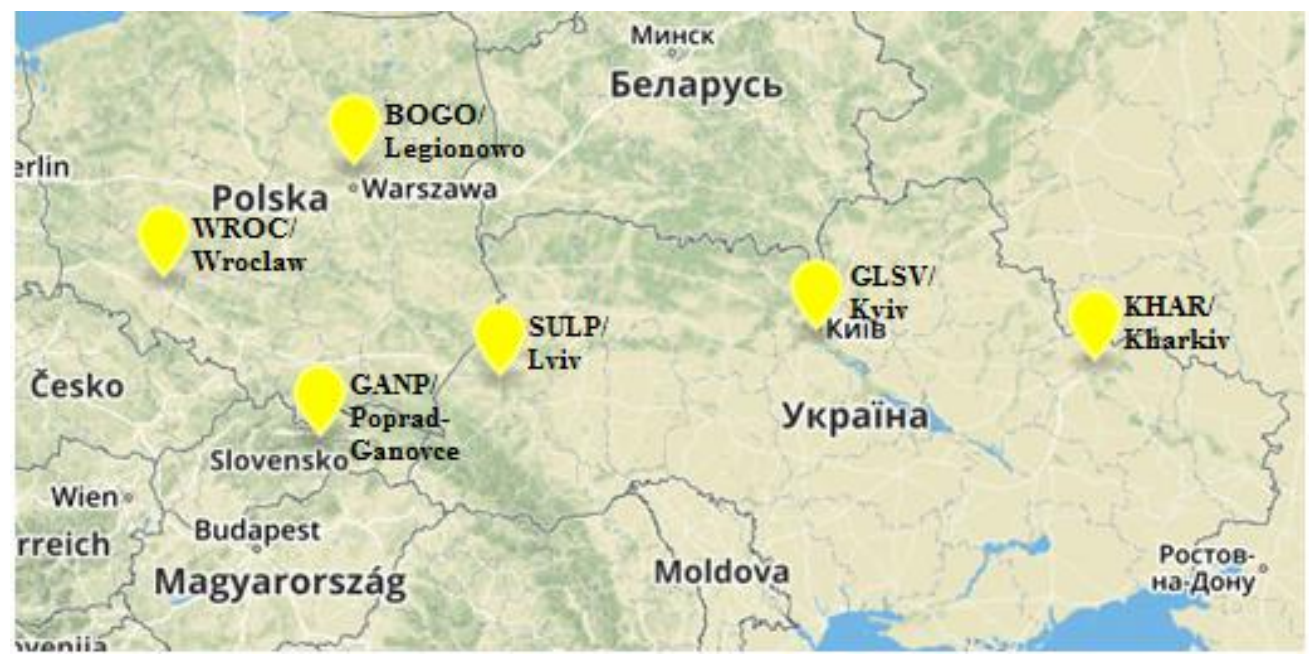

Fig. 2. Map of research stations location. Source: Authors based on Google.

It was used data from 1 January to 30 June of 2018. Sounding data were downloaded from the Internet resource of Atmospheric Research Services at the University of Wyoming (Canada) [5] using a specially developed program atmosound, where obtained in this way measurement data was calculated by integrating of vertical sounding profiles with the addition of the standard model of the atmosphere (US Standard Atmosphere) [25].

Selected GNSS stations are included in the EUREF Permanent GNSS Network (EPN) that is why their observations data were downloaded from the official EPN server [16]. 
Table 1. Coordinates and distances between aerological and GNSS stations.

\begin{tabular}{|c|c|c|c|c|c|c|c|c|c|}
\hline \multirow{2}{*}{ Country } & \multicolumn{4}{|c|}{ GNSS Stations } & \multicolumn{4}{|c|}{ Aerological Stations } & \multirow{2}{*}{$\begin{array}{r}\text { Dist } \\
\text { (km) }\end{array}$} \\
\hline & NAME & $\begin{array}{l}\text { B } \\
(\mathrm{deg})\end{array}$ & $\mathrm{L}(\mathrm{deg})$ & $\mathrm{H}(\mathrm{m})$ & NAME & B (deg) & $\mathrm{L}(\mathrm{deg})$ & $\mathrm{H}(\mathrm{m})$ & \\
\hline \multirow{2}{*}{ Poland } & BOGO & 52,5 & 21,0 & 149,6 & Legionowo & 52,4 & 21,0 & 96,6 & 9,9 \\
\hline & WROC & 51,1 & 17,1 & 180,0 & Wroclaw & 51,1 & 17,0 & 116,0 & 6,0 \\
\hline $\begin{array}{c}\text { Slovak } \\
\text { Republic } \\
\end{array}$ & GANP & 49.0 & 20.3 & 746.0 & $\begin{array}{l}\text { Poprad- } \\
\text { Ganovce }\end{array}$ & 49.0 & 20.3 & 706.0 & 1.1 \\
\hline \multirow{3}{*}{ Ukraine } & GLSV & 50.4 & 30.5 & 226.8 & Kyiv & 50.4 & 30.6 & 167.0 & 6.0 \\
\hline & KHAR & 50.0 & 36.2 & 201.0 & Kharkiv & 50.0 & 36.1 & 155.0 & 9.3 \\
\hline & SULP & 49.8 & 24.0 & 370.5 & Lviv & 49.8 & 24.0 & 323.0 & 5.4 \\
\hline
\end{tabular}

Source: Authors.

GipsyX software was installed for processing in PPP mode, with using the recommended script gd2e.py. ZHD values calculated based on the heights of selected GNSS stations by using the following equation [8]:

$$
Z H D=1.013 \cdot 2.27 \cdot \exp (-0.000166 h)
$$

where $h$ is the height of the station.

Values of $Z W D$ and gradients $\left(G_{N}, G_{E}\right)$, were modeled as random walk variables from $0.5-1$ to $5 \mathrm{~mm} / \sqrt{h}$, as it is recommended by GipsyX documentations. In calculation process it was used GMF mapping function [22]. Detailed description of the algorithm can be found in [8]. The obtained values of ZTD accuracy estimations are given in Table 2 , where $\mu$ is average value and $\sigma-$ standard deviation.

The comparison results, which are given in Table 2, are showing a sufficient level of harmonization with a standard deviation of about $2 \mathrm{~mm}$ on stations GANP - PopradGanovce (the distance between each is near $1 \mathrm{~km}$ ), and $65 \mathrm{~mm}$ on stations BOGO Legionowo (the distance between each is near $10 \mathrm{~km}$ ), for example. These results confirm our assumption that the less distances between GNSS and aerological stations, provide the greater similarity of the atmosphere affects on those measurements. It is important to note, that comparison results are affected by GNSS observation errors and sounding errors alike. In any case, the resulting level of harmonization is fully compliant with the requirements for accuracy of tropospheric parameters. 
Table 2. ZTD accuracy estimations.

\begin{tabular}{|c|c|c|c|c|c|c|c|}
\hline $\begin{array}{c}\text { Name } \\
\text { of stations }\end{array}$ & $\begin{array}{c}\text { Estim. } \\
\text { parameters }\end{array}$ & Jan & Feb & March & April & May & June \\
\hline \multirow{2}{*}{$\begin{array}{c}\text { BOGO- } \\
\text { Legionowo }\end{array}$} & $\mu, \mathrm{m}$ & 0.086 & 0.090 & 0.066 & -0.009 & 0.066 & 0.070 \\
\cline { 2 - 8 } & $\sigma, \mathrm{m}$ & 0.086 & 0.090 & 0.066 & 0,009 & 0.066 & 0.070 \\
\hline $\begin{array}{c}\text { WROC- } \\
\text { Wroclaw }\end{array}$ & $\boldsymbol{\sigma}, \mathrm{m}$ & -0.015 & -0.013 & -0.015 & -0.015 & -0.010 & -0.014 \\
\cline { 2 - 8 } & $\mu, \mathrm{m}$ & -0.003 & 0,000 & 0,000 & -0.002 & -0.003 & -0.002 \\
\hline $\begin{array}{c}\text { GANP }- \\
\text { Poprad- } \\
\text { Ganovce }\end{array}$ & $\sigma, \mathrm{m}$ & 0,003 & 0,000 & 0,000 & 0,002 & 0,003 & 0,002 \\
\cline { 2 - 8 } & $\mu, \mathrm{m}$ & $-0,024$ & -0.021 & -0.025 & -0.010 & -0.014 & -0.017 \\
\hline $\begin{array}{c}\text { GLSV- } \\
\text { Kyiv }\end{array}$ & $\sigma, \mathrm{m}$ & 0,024 & 0,021 & 0,025 & 0,010 & 0,014 & 0,017 \\
\cline { 2 - 8 } & $\mu, \mathrm{m}$ & -0.022 & $-0,024$ & $-0,024$ & -0.022 & -0.017 & - \\
\hline $\begin{array}{c}\text { KHAR- } \\
\text { Kharkiv }\end{array}$ & $\sigma, \mathrm{m}$ & 0,022 & 0,024 & 0,024 & 0,022 & 0,017 & - \\
\cline { 2 - 8 } & $\mu, \mathrm{m}$ & 0,021 & 0,016 & 0,018 & 0,010 & 0,006 & -0.012 \\
\hline $\begin{array}{c}\text { SULP - } \\
\text { Lviv }\end{array}$ & $\sigma, \mathrm{m}$ & 0,021 & 0,016 & 0,018 & 0,010 & 0,006 & 0,012 \\
\cline { 2 - 8 }
\end{tabular}

Source: Authors.

At the second stage of our research, for analyzing of obtaining STD values, it was chosen the results of processing GNSS observations on the station SULP. So, STD values that derived from calculations by formula (3) were compared with the corresponding values obtained using software module Atmosphere App from Trimble Pivot Platform [23], by analysis of its differences:

$$
\delta S T D=S T D_{\text {GipsyX }}-S T D_{\text {AtmosphereApp }}
$$

where:

$S T D_{\text {GipsyX }}-S T D$ values obtained using GipsyX software,

$S T D_{\text {AtmosphereApp }}-S T D$ values obtained using Atmosphere App software module,

$\delta S T D$ - differences between $S T D$ values obtained using those software's.

For clarity, it was built graphs of $S T D$ values change and their differences $\delta S T D$ during the period of our research monthly (fig. 2-3). Based on fig. 2-3 we can see that $S T D$ values can reach to $17 \mathrm{~m}$ at low elevation angles. 


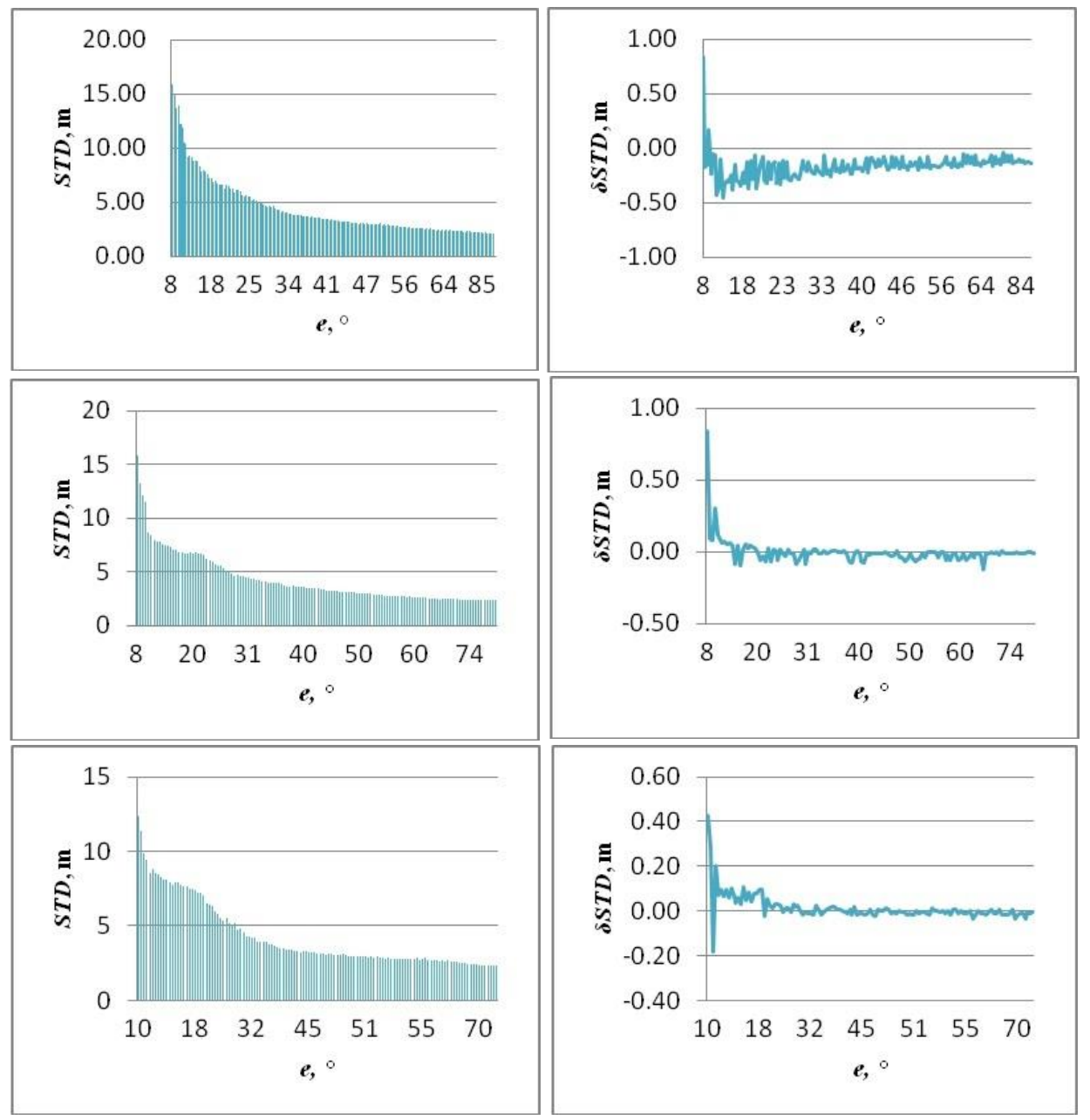

Figure 2. Graphs of STD values change and their differences $\delta S T D$ on station SULP during January - March of 2018. Source: Authors. 


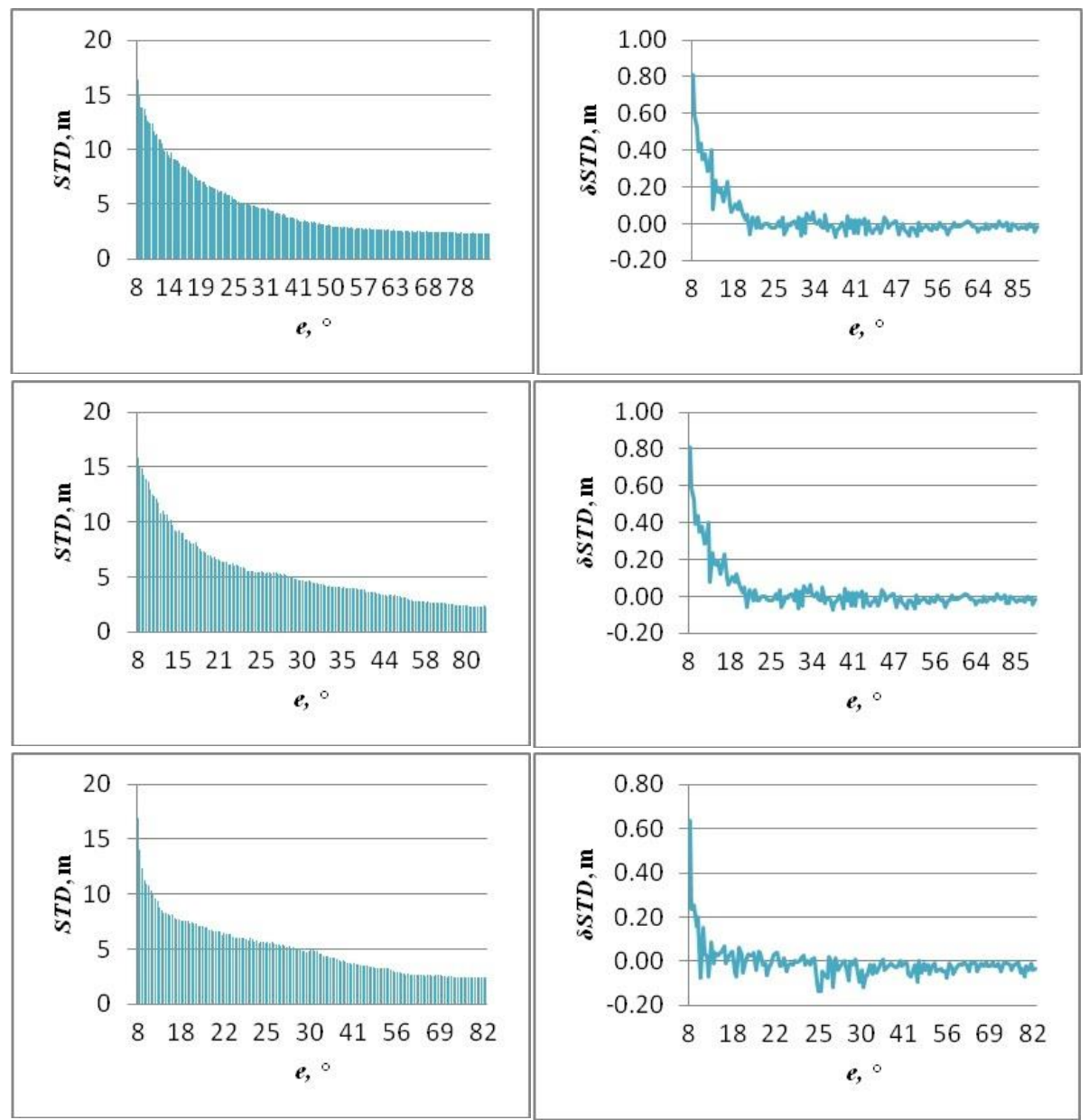

Figure 3. Graphs of STD values change and their differences $\delta S T D$ on station SULP during April - June of 2018. Source: Authors.

Also, it was built a generalized graph, which displays the statistics of average STD values by elevation angles during our research period (fig. 4). 


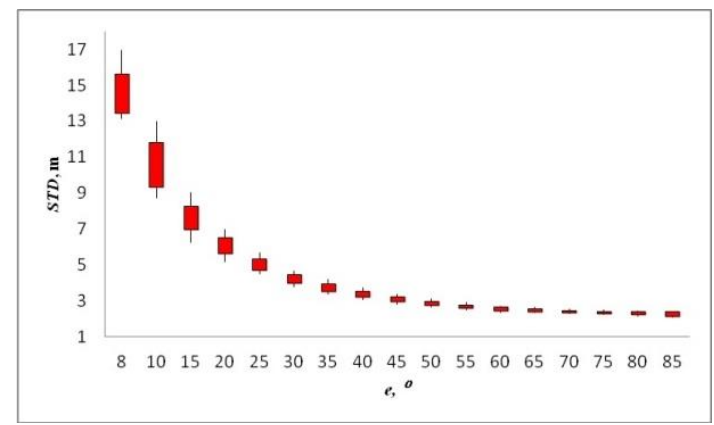

Figure 4. Statistics of STD average values by elevation angles on station SULP during January - June 2018. Source: Authors.

To construct this graph, the $S T D$ values were grouped with increasing of elevation angle (from $8^{\circ}$ to $85^{\circ}$, in increments of $5^{\circ}$ ).

In this graph:

- $\quad$ bottom of "line" corresponds to the minimum average STD value of individual group;

- bottom of "block" corresponds to value of one standard deviation below the mean $(\mu+\sigma)$;

- $\quad$ top of "block" is $(\mu+\sigma)$;

- $\quad$ top of "line" is the maximum average $S T D$ value.

\section{CONCLUSIONS}

In this article were proposed GNSS observations processing with the using of GipsyX software in PPP mode. As a result we have gotten the atmospheric parameters from GNSS observation data, including values of $Z T D$, gradients $G_{N}, G_{E}$ and STD The results of algorithms development and testing for solving the problem of STD determination along the path of each satellite, for certain elevation angles and azimuths, instead of getting one ZTD value that consisting of all visible satellites at once are presented. Comparison of ZTD values obtained from GNSS stations processing and integration of vertical sounding profiles of aerological stations were satisfactory and gave us confidence in the possibilities of determination STD values. As a result of the conducted studies, it has been shown that the developed algorithms allow us to obtain reliable solutions to the problem and to perform definitions with a millimeter level of accuracy. The results showed that the proposed method is valid. 


\section{REFERENCES}

[1] Alberding GNSS Status Software, [online:] http://194.42.206.27/cgibin/beacon.cgi?mod=show_map\&lang [access: 14.07.2018].

[2] Bar-Sever Y.E., Kroger P.M., and Borjesson J.A., Estimating Horizontal Gradients of Tropospheric Path Delay with a single GPS Receiver. Journal of Geophysical Research, Volume103, Issue B3, 1998, pp 5019-5035.

[3] Bernese GPS Software, Version 5.2 [online:] http://www.bernese.unibe.ch/docs/DOCU52.pdf [access: 14.07.2018].

[4] Byung-Kyu Ch., Jeong-Ho B., Sung-Ki Ch., Jong-Uk P., and Pil-Ho P. Development of Precise Point Positioning Method Using Global Positioning System Measurements. Journal of Astronomy and Space Sciences, Volume. 28, No. 3, pp. 217-223.

[5] Internet resource of Atmospheric Research Services at the University of Wyoming (Canada) [Online:] http://weather.uwyo.edu/upperair/sounding.html [access: 14.07.2018].

[6] Introduction to GAMIT/GLOBK. At http://www-gpsg.mit.edu/ simon/gtgk/Intro_GG.pdf [access: 14.07.2018].

[7] GipsyX Beta-Release Notes. $A t$ https://gipsy-oasis.jpl.nasa.gov/gipsy/docs/ReleaseNotesGipsyX-Beta.pdf [access: 14.07.2018].

[8] GipsyX Beta documentation.

[9] Kablak N. I., Savchuk S. H., Dystantsiynyy monitorynh atmosfery (in Ukrainian). Kosmichna nauka i tekhnolohiya. T. 18, № 2, 2012, S. 20-25.

[10] Kablak N., Suchasni pidkhody do vyznachennya ta vykorystannya troposfernykh zatrymok GNSS-syhnaliv (in Ukrainian). Heodeziya, kartohrafiya i aerofotoznimannya, 2009, Vypusk. 72, S. 22-27.

[11] Kačmařík M., Douša Ja., Dick G., Zus F., Brenot H., Möller G., Pottiaux E., Kapłon Ja., Hordyniec P., Václavovic P., and Morel L., Inter-technique validation of tropospheric slant total delays. Atmospheric Measurement Techniques, Volume. 10, Issue 6, 10, 2017, pp. 2183-2208.

[12] Khoptar A., Metodyka vyznachennya troposfernykh parametriv z sumisnykh danykh GNSS i SLR sposterezhen (in Ukrainian). Zbirnyk naukovykh prats' ZHT "Suchasni dosyahnennya heodezychnoyi nauky ta vyrobnytstva”, 2017, Vypusk. II (34), C. 51-54.

[13] Khoptar A., Porivnyal'nyy analiz pidkhodiv vyznachennya troposfernoyi zatrymky za danymy radiozonduvannya ta GNSS sposterezhen' (in Ukrainian). Zbirnyk materialiv Mizhnarodnoyi naukovo-tekhnichnoyi konferentsiyi molodykh vchenykh GeoTerrace2017, L'viv, Ukrayina, 2017.

[14] Krueger E., Schuler T., Arbesser-Rastburg B., The Standard Tropospheric Correction Model for the European Satellite Navigation System Galileo. Proceeding General Assembly URSI, New Delhi, India, 2005.

[15] Mendes V.B., Modeling the Neutral-Atmosphere Propagation Delay in Radiometric Space Techniques. Technical Report, No. 199; New Brunswick, Canada, 1999.

[16] Official EPN server [online:] http://epncb.oma.be/ftp/obs/[access: 14.07.2018]. 
[17] Pazyak M. V., Zablots'kyy F. D., Porivnyannya volohoyi skladovoyi zenitnoyi troposfernoyi zatrymky, vyvedenoyi iz GNSS-vymiryuvan', z vidpovidnoyu velychynoyu iz radiozonduvannya (in Ukrainian). Heodeziya, kartohrafiya i aerofotoznimannya, 2015, Vypusk. 81, S. 16-24.

[18] Popov D. O., Distantsionnoye zondirovaniye okruzhayushchey sredy s ispol'zovaniyem izlucheniy global'nykh navigatsionnykh sputnikovykh sistem: diss. kand. fiz.-mat. nauk: 01.04.03 (in Ukrainian), Khar'kov, 2017.

[19] Project HUSKROUA/1101/252 (SES project). At http://meteognss.net [access: 14.07.2018].

[20] Savchuk S. H., Zablots'kyy F. D., Monitorynh troposfernoyi vodyanoyi pary $v$ zakhidniy transkordonniy zoni Ukrayiny (in Ukrainian). Heodeziya, kartohrafiya i aerofotoznimannya, 2016, Vypusk. 83, S. 21-33.

[21] Solheim F.S., Vivekanandan J., Ware R.H., Rocken Ch., Propagation delays induced in GPS signals by dry air, water vapor, hydrometeors, and other particulates. Journal of Geofisical Research, Volume. 104, No. D8, Apr. 27, 1999, pp. 9663-9670.

[22] Tregoning P., Boehm J., Niell A., Schuh H., Global Mapping Function (GMF): A new empirical mapping function based on numerical weather model data. Geophysical Research Letters, Volume 33, Issue 7, Apr. 4, 2006.

[23] Trimble Pivot Platform GNSS Infrastructure Software. Release notes (V. 2.1). At https://www.trimble.com/infrastructure/pdf/Pivot_ReleaseNotes.pdf [access: 14.07.2018].

[24] Turchyn N., Zablots'kyy F., Suchasni pidkhody do vyznachennya troposfernoyi zatrymky ta yiyi skladovykh (in Ukrainian). Heodeziya, kartohrafiya i aerofotoznimannya, 2013, Vypusk. 78, S. 155-159.

[25] U.S. Standard Atmosphere, U.S. Government Printing Office, Washington, 1976.

[26] Zumberge J.F., Heflin M.B., Jefferson D.C., Watkins M.M., and Webb F.H., Precise point positioning for the efficient and robust analysis of GPS data from large networks. Journal of Geophysical Research, Volume. 6, No. 2, May 28, 2015, pp. 5005-5017.

Received September 2018

Reviewed November 2018

Accepted December 2018

\section{STEPAN SAVCHUK}

Polish Air Force University

Dywizjonu 303 bldg. 33, 08-521 Dęblin, Poland

e-mail: $\underline{\text { s.savchuk@law.mail.pl }}$

\section{ALINA KHOPTAR}

Lviv Polytechnic National University

6 Karpinskyi str, bldg. 2, Lviv, Ukraine

e-mail: alina.khoptar@gmail.com 


\section{STRESZCZENIE}

Globalne systemy nawigacji satelitarnej - GNSS - dają możliwości analizy parametrów atmosferycznych do rozwiązywania wielu zadań związanych z monitorowaniem atmosfery. Autorzy tego artykułu zademonstrowali możliwość estymacji opóźnienia troposferycznego w kierunku do satelity za pomocą metody absolutnego precyzyjnego pozycjonowania - PPP. Parametry atmosferyczne, uzyskane z obserwacji GNSS, w tym opóźnienie troposferyczne w kierunku zenitu, gradienty poziomy i opóźnienie troposferyczne w kierunku do satelity są analizowane i oceniane. Otrzymaliśmy opóźnienia troposferyczne w kierunku do satelity dla każdego satelity pod pewnymi kątami wzniesienia i azymutu w każdej chwili, zamiast uzyskać pojedyncze opóźnienie troposferyczne w kierunku zenitu złożone z wszystkich widzialnych satelitów naraz. Uzyskane wyniki wykazały, że sugerowana metoda była prawidłowa. 